\title{
Antibiotic resistance and metallo-beta-lactamase positivity in carbapenem-resistant non-fermentative Gram negative bacilli
}

\author{
Karbapenemlere dirençli non-fermenter Gram negatif basillerde \\ antibiyotik direnci ve metallo-beta-laktamaz pozitifliği
}

Mustafa GÜZEL ${ }^{1}, \quad$ Yasemin GENÇ ${ }^{2}, \quad$ Altan AKSOY ${ }^{2}, \quad$ Penka MONCHEVA ${ }^{1}, \quad$ Petya HRISTOVA ${ }^{1}$

\section{ABSTRACT}

Objective: Antibiotic resistance in Gram negative bacteria is an increasing problem worldwide and a challenging issue for the physicians in both nosocomial and community-acquired infections. Infections caused by metallo-beta-lactamase (MBL)-producing bacteria are particularly threatening as the resistance genes of these bacteria may render an entire antibiotic class ineffective. Moreover, the rates of multidrug-resistant strains are also higher among MBL-producing bacteria. Multidrug resistance has been gradually increasing among non-fermentative Gram-negative bacilli (NFGNB). The present study aimed to investigate resistance rates of carbapenem-resistant NFGNB isolated from patients' specimens to other antibiotics and to evaluate MBL production by E-test method.

Method: Carbapenem-resistant NFGNB, which were isolated from the inpatients' specimens sent from January 2014 through March 2015 to Ankara Numune Training and Research Hospital Medical Microbiology Laboratory, were included. Imipenem- and/or meropenem-resistant strains were considered as carbapenem-resistant. Meropenem/meropenem+EDTA E-test strips were used for phenotypic MBL detection.

Results: The study included 110 carbapenemresistant NFGNB strains. Of these strains, $44.5 \%$ were Acinetobacter baumannii and $36.4 \%$ were Pseudomonas aeruginosa. The NFGNB strains were mostly isolated from tracheal aspirate $(37.9 \%)$, followed by blood $(22.3 \%)$, wound $(17.5 \%)$, and urine $(13.6 \%)$ specimens. When all carbapenem-resistant NFGNB strains were considered, the highest rate of resistance was ampicillin-sulbactam

\section{ÖZET}

Amaç: Gram negatif bakterilerde görülen antibiyotik direnci tüm dünyada giderek artan bir sorundur ve hem hastane içi hem de toplum kökenli enfeksiyonlarda hekimleri zorlayan bir konudur. Metallo-beta-laktamaz (MBL) üreten bakteriler ile olușan enfeksiyonlar özellikle endișe vericidir; çünkü bu bakterilerdeki direnç genleri bir sınıf antibiyotiğin tümünü etkisiz kılabilirler. Ayrıca, MBL üreten bakteriler arasında çoklu ilaç dirençli suşların oranı da yüksek olmaktadır. Çoklu ilaç direnci non-fermenter Gram negatif basiller (NFGNB) arasında giderek artış göstermektedir. Bu çalıșmada, hasta örneklerinden izole edilen karbapenem dirençli NFGNB (non-fermenter Gram negatif basiller)'de diğer antibiyotiklere direnç oranlarının ve E-test yöntemi ile MBL üretiminin araștırılması amaçlanmıștır.

Yöntem: Ankara Numune Eğitim ve Araștırma Hastanesi Tıbbi Mikrobiyoloji Laboratuvarına Ocak 2014 ve Mart 2015 yılları arasında gönderilen yatan hasta örneklerinden izole edilen karbapenem dirençli NFGNB çalıșmaya dahil edilmiștir. İmipenem ve/veya meropenem dirençli sușlar karbapenem dirençli olarak kabul edilmiștir. Fenotipik olarak MBL tayini için meropenem/ meropenem+EDTA E-test stripleri kullanılmıștır.

Bulgular: Çalışmaya 110 karbapenem dirençli NFGNB suș dahil edilmiștir. Bunların \%44,5'i Acinetobacter baumannii, \%36,4'ü Pseudomonas aeruginosa'dır. NFGNB suşlarının en fazla izole edildiği örnek trakeal aspirat $(\% 37,9)$ olup bunu \%22,3 ile kan, \%17,5 ile yara ve \%13,6 ile idrar örneği izlemiștir. Karbapenem dirençli tüm NFGNB

Department of Mikrobiology. Univercity of Sofia "st. Kliment Ohridski" Faculy of Biology, SOFIA, BULGARIA

${ }^{2}$ Ankara Numune Research and Education Hospital, Medical Mikrobiology, ANKARA, TURKEY

İletisim/Corresponding Author : Mustafa GÜZEL

Department of Mikrobiology. Univercity of Sofia "st. Kliment Ohridski" Faculy of Biology, SOFIA, BULGARIA

Tel : +902164620284_E-posta /E-mail : dr.mustafaguzel@hotmail.com

Geliş Tarihi / Received : 28.05 .2015

Kabul Tarihi / Accepted : 04.09.2015

DOI ID : 10.5505/TurkHijyen.2016.55706

Güzel M, Genc Y, Aksoy A, Moncheva P, Hristova P. Antibiotic resistance and metallo-beta-lactamase positivity in carbapenem-resistant non-fermentative Gram negative bacilli. Turk Hij Den Biyol Derg, 2016; 73(1): 9-14. 
(95.5\%), followed by ciprofloxacin $(87.8 \%)$, and cefepime (83.3\%). Of 110 strains, only $1(0.9 \%)$ was determined to be MBL positive. This was an Acinetobacter baumannii isolated from urine sample.

Conclusion: Detection of enzyme-producing strains by appropriate antibiogram and routine $\mathrm{MBL}$ screening of clinical isolates, surveillance, and rational antibiotic use are essential in the control of resistant NFGNB infections, the rate of which is gradually increasing and the treatment of which is difficult and costly.

Key Words: Gram negative bacteria, metallo-betalactamase, carbapenem suşları göz önüne alındığında, en yüksek direnç oranları sırasıyla ampisilin-sulbaktam $(\% 95,5)$, siprofloksasin $(\% 87,8)$ ve sefepim $(\% 83,3)$ için gözlenmiștir. MBL pozitifliği 110 suștan yalnızca birinde $(\% 0,9)$ saptanmıștır. Bu suș idrar örneğinden izole edilen bir $A$. baumannii'dır.

Sonuç: Giderek artan ve tedavisi güç ve maliyetli olan dirençli NFGNB enfeksiyonlarının kontrolünde klinik izolatların uygun antibiyogramı ve rutin MBL taraması ile enzim üreten suşların saptanması, sürveyansı ve akılcı antibiyotik kullanımı esastır.

Anahtar Kelimeler: Gram negatif bakteri, metallobeta-laktamaz, karbapenem

\section{INTRODUCTION}

Antibiotic resistance in Gram negative bacteria is an increasing problem worldwide and a challenging issue for the physicians in both nosocomial and community-acquired infections. The resistance problem has gained more importance along with the occurrence of antibiotic-degrading enzymes such as extended-spectrum beta-lactamases (ESBLs), carbapenemases (KPCs), and metallo-beta-lactamases (MBLs) among Enterobacteriaceae, Pseudomonas and Acinetobacter species (1). Infections caused by MBL-producing bacteria are particularly threatening as these resistance genes are usually located in transferable plasmids and may render an entire antibiotic class ineffective (2). Besides, the rates of multidrug- and pandrug-resistant strains are higher among MBL-producing bacteria (3).

Multidrug resistance has been gradually increasing among non-fermentative Gram negative bacilli (NFGNB). Treatment of infections caused by bacteria resistant to the primary therapeutic agents such as beta-lactam, fluoroquinolone, aminoglycoside, and carbapenem group antibiotics is difficult and leads to a high cost (4). The present study aimed to investigate resistance rates of carbapenem resistant NFGNB isolated from patients' specimens to other antibiotics and to evaluate $M B L$ production by E-test method.

\section{MATERIALS and METHODS}

Carbapenem resistant 110 NFGNB, which were isolated from the clinical specimens sent from January 2014 through March 2015 to Ankara Numune Training and Research Hospital Medical Microbiology Laboratory, were included in the study. All of the specimens were obtained from inpatients.

Bacterial identification was performed by matrixassisted laser desorption/ionization time-of-flight mass spectrometry (MALDI-Tof-MS). Antibiotic susceptibility test was performed by the BD Phoenix fully-automated system according to the Clinical and Laboratory Standards Institute (CLSI) Guideline, 2014. Imipenemand/or meropenem-resistant strains were considered as carbapenem resistant.

Meropenem / meropenem+EDTA E-test strips (Biomerieux) were used for phenotypic MBL detection. Dose content of the meropenem / meropenem+EDTA E-test strip was $8 / 20.125-8 / 0.032-2 \mu \mathrm{g} / \mathrm{mL}$. The test was accepted as MBL positive in case of a minimum inhibitory concentration (MIC) value of MP / MP+EDTA was $\geq 8$ and in the presence of a phantom zone or deformation of the zone. The PASW Statistics for Windows version 18.0 (SPSS Inc., Chicago, IL, USA) was used for statistical analyses. Descriptive statistics were presented as number and percentage for categorical variables. 


\section{RESULTS}

In a total of 110 carbapenem resistant NFGNB strains, $44.5 \%$ were Acinetobacter baumannii and $36.4 \%$ were Pseudomonas aeruginosa. P. putida were not included in the analysis because of insufficient number. The NFGNB isolated clinical specimens were grouped as abscess/wound, urine, blood, tracheal aspirate/sputum and sterile body fluids. The NFGNB strains were mostly isolated from tracheal aspirate (37.9\%), followed by blood (22.3\%), wound $(17.5 \%)$, and urine $(13.6 \%)$ specimens.

While $P$. aeruginosa was the most frequently isolated bacteria in the abscess/wound and urine specimens $(42.9 \%$ and $46.2 \%$, respectively), $A$. baumanni was the most frequently isolated bacteria in the blood and tracheal aspirate/sputum specimens (60.9\% and $48.8 \%$, respectively). However, there was no significant difference between the clinical specimens and the distribution of isolated bacteria $(p=0.793)$. The distribution of carbapenem resistant NFGNB strains according to species and clinical specimens are demonstrated in Table 1. When all carbapenemresistant NFGNB strains were considered, the highest rate of resistance was ampicillin sulbactam (95.5\%), followed by ciprofloxacin (87.8\%) and cefepime (83.3\%). Antibiotic resistance rates of carbapenem resistant NFGNB are demonstrated in Table 2.

Totally only one $(0.9 \%)$ of 110 strains, was determined to be MBL positive. This was an Acinetobacter baumannii isolated from the urine sample. In the present study, only one strain with a MIC (minimum inhibitory concentration) ratio of $>8$ was observed and phantom zone or zone deformation was not observed.

Table 1. Distribution of carbapenem resistant non fermentative Gram negative bacilli according to species and clinical specimens

\begin{tabular}{|c|c|c|c|c|c|}
\hline & \multirow{2}{*}{$\mathrm{n}$} & A. baumannii & P. aeruginosa & S. maltophilia & \multirow{2}{*}{$\mathrm{p}$} \\
\hline & & n (\%) & n (\%) & n (\%) & \\
\hline Abscess/Wound & 21 & $8(38.1)$ & $9(42.9)$ & $4(19.0)$ & \multirow{4}{*}{0.793} \\
\hline Urine & 13 & $5(38.5)$ & $6(46.2)$ & $2(15.4)$ & \\
\hline Blood & 23 & $14(60.9)$ & $6(26.1)$ & $3(13.0)$ & \\
\hline Tracheal aspirate / Sputum & 41 & $20(48.8)$ & $16(39.0)$ & $5(12.2)$ & \\
\hline
\end{tabular}

Sterile body fluids, including cerebrospinal fluid $(\mathrm{n}=1)$, peritoneal fluid $(\mathrm{n}=1)$, pleural fluid $(\mathrm{n}=1)$, and bile $(\mathrm{n}=1)$, and $P$. putida $(\mathrm{n}=1)$ were not included in the analysis because of insufficient number.

Table 2. Antibiotic resistance rates of carbapenem resistant non fermentative Gram negative bacilli

\begin{tabular}{|c|c|c|c|c|c|}
\hline & A. baumannii & P. aeruginosa & P. putida & S. maltophilia & All NFGNB \\
\hline & n (\%) & n (\%) & n (\%) & n (\%) & n (\%) \\
\hline Amikacin & $42(85.7 \%)$ & $19(47.5 \%)$ & $1(100.0 \%)$ & - & $62(68.9 \%)$ \\
\hline Gentamicin & $43(87.8 \%)$ & $28(70.0 \%)$ & $1(100.0 \%)$ & - & $72(80.0 \%)$ \\
\hline Ampicillin Sulbactam & $46(93.9 \%)$ & $37(97.4 \%)$ & $1(100.0 \%)$ & - & $84(95.5 \%)$ \\
\hline Piperacillin Tazobactam & $48(98.0 \%)$ & $25(62.5 \%)$ & $1(100.0 \%)$ & - & $74(82.2 \%)$ \\
\hline Cefepime & $48(98.0 \%)$ & $26(65.0 \%)$ & $1(100.0 \%)$ & - & $75(83.3 \%)$ \\
\hline Ceftazidime & 47 (95.9\%) & $26(65.0 \%)$ & $0(0.0 \%)$ & - & $73(81.1 \%)$ \\
\hline Ciprofloxacin & 47 (95.9\%) & $31(77.5 \%)$ & $1(100.0 \%)$ & - & $79(87.8 \%)$ \\
\hline Levofloxacin & 47 (95.9\%) & $28(71.8 \%)$ & $1(100.0 \%)$ & $4(20.0 \%)$ & $80(73.4 \%)$ \\
\hline Trimethoprim-Sulfamethoxazole & 39 (79.6\%) & $39(100.0 \%)$ & $1(100.0 \%)$ & $5(25.0 \%)$ & $84(77.1 \%)$ \\
\hline Colistin & $3(6.1 \%)$ & $2(5.0 \%)$ & $0(0.0 \%)$ & - & $5(5.6 \%)$ \\
\hline
\end{tabular}

NFGNB, non fermentative Gram negative bacilli. 


\section{DISCUSSION}

Carbapenem resistant NFGNB are usually resistant to other antibiotic groups such as cephalosporins, aminoglycosides, quinolones and beta lactam + beta lactamase inhibitors as well. This multiple resistance of NFGNB has also been demonstrated in the studies (5-7). In the present study, carbapenemresistant NFGNB were found to be resistant to the other antibiotics by $69 \%-95 \%$. There was no significant difference between the clinical specimens regarding antibiotic resistance rates.

Antibiotic options are quite limited in multipleresistant NFGNB infections; old but well-known polymyxins, which have become available again, are an option in the treatment of resistant strains. Although types of polymyxins range from $A$ to $E$, only polymyxins $B$ and $E$ (colistin) are being marketed and used in clinical practice (8). Colistin resistance among NFGNB has been reported to be low as $0-1 \%(5,6,9,10)$ and it was determined to be $5.6 \%$ in the present study. Although resistance to polymyxins is lower than $10 \%$ in many geographic regions, higher resistance rates have been reported for the Mediterranean and South-East Asia (Korea and Singapore) regions (11). Increased use of broad spectrum cephalosporins, beta lactam + beta lactamase inhibitor combinations, carbapenems, fluoroquinolones, and aminoglycosides, which are the main drug groups used in the treatment of Gramnegative bacilli, has been reported to be associated with increased drug resistance which shows variation among bacterial species $(12,13)$. Likewise, it can be suggested that increased colistin use would cause a gradual increase in colistin resistance.

In the present study, MBL production was evaluated by $\mathrm{E}$-test method in the carbapenem resistant NFGNB strains isolated from the clinical specimens. Phenotypic tests such as different double disc synergy tests (DDST), carbapenem/EDTA combined disk test (CDT), and E-test and genotypic methods (gene detection via polymerase chain reaction) can be used to detect MBL in resistant bacteria (9). It has been demonstrated that there are differences between phenotypic tests in terms of the rates of detecting MBL positivity and that the use of a single method might be insufficient and better outcomes could be obtained with the use of more than one method (5). Nevertheless, Yan et al. (14) reported that the sensitivity and specificity of E-test in detecting MBL in Pseudomonas spp. and A. baumannii were $87 \%$ and $100 \%$, respectively. Farajzadeh Sheikh et al. (6) reported that the sensitivity and specificity of E-test in detecting $\mathrm{MBL}$ were $100 \%$ and $24.6 \%$, respectively, among carbapenem resistant $P$. aeruginosa strains. In the study, MBL positivity has been reported in varying rates in the studies on carbapenem-susceptible and carbapenem resistant NFGNB strains. Gupta et al. (10) investigated ESBL, AmpC beta-lactamase, and MBL production via phenotypic tests in $A$. baumannii strains $(n=100)$ isolated from the wound cultures of the burn patients and determined that these three resistance mechanisms coexisted in $25 \%$ of the isolates. Szejbach et al. (9) determined MBL positivity to be $66.7 \%$ by DDST, $94.4 \%$ by imipenem/EDTA CDT, and $88.9 \%$ by $\mathrm{E}$ test in carbapenem resistant $A$. baumannii isolates $(n=78)$. Peter et al. (7) reported the MBL positivity by means of gene detection to be $33.8 \%$ in meropenem non-susceptible $P$. aeruginosa isolates. Kaleem et al. (15) determined MBL positivity by E-test to be $84 \%$ for Acinetobacter spp. and $78 \%$ for $P$. aeruginosa among carbapenem resistant isolates. In the present study, E-test method was used in detecting MBL production among carbapenem resistant NFGNB strains and MBL positivity was determined in only one $(0.9 \%)$ out of 110 strains. The low MBL positivity might be resulted from using E-test alone or another potential resistance mechanism. We are in the opinion that the low MBL positivity is due to OXA type genes which is the most common cause of carbapenem resistance in Turkey (16).

Education of health care staff prescribing medication, infection control and antibiotic 
management, implementation of an active surveillance system, restriction of non human use of antimicrobials (e.g. livestock), and sharing data about resistant strains at national and international level are recommended to control resistant bacteria (17). It has been demonstrated that a successful infection control and surveillance may result in a decrease in the rates of resistant strains (18).
In conclusion, detection of enzyme-producing strains by appropriate antibiotic susceptibility tests and routine MBL screening of clinical isolates, surveillance and rationale antibiotic usage are essential parameters in the control of gradually increasing resistant NFGNB infections and the treatment of them which costs money and needs so many interventions.

\section{REFERENCES}

1. Curcio D. Multidrug resistant Gram negative bacterial infections: are you ready for the challenge? Curr Clin Pharmacol, 2014; 9 (1): 27-38.

2. Fast W, Sutton LD. Metallo-B-lactamase: inhibitors and reporter substrates. Biochim Biophys Acta, 2013; 1834 (8): 1648-59.

3. Ranjan S, Banashankari G, Babu PS. Comparison of epidemiological and antibiotic susceptibility pattern of metallo beta lactamase positive and metallo beta lactamase negative strains of Pseudomonas aeruginosa. J Lab Physicians, 2014; 6(2): 109-13.

4. McGowan JE Jr. Resistance in non fermenting Gram negative bacteria: multidrug resistance to the maximum. Am J Infect Control, 2006; 34 (5 Suppl 1): S29-37; discussion S64-73.

5. Bulut $Y$, Cağlar H. Gram negatif non-fermantatif bakterilerde metallo beta laktamaz enziminin farklı yöntemlerle gösterilmesi. FÜ Sağ Bil Tıp Derg, 2013; 27 (3): 135-40.

6. Farajzadeh Sheikh A, Rostami S, Jolodar A, Tabatabaiefar MA, Khorvash F, Saki A, et al. Detection of metallo beta lactamases among carbapenem resistant Pseudomonas aeruginosa. Jundishapur J Microbiol, 2014; 7 (11): e12289.

7. Peter S, Lacher A, Marschal M, Hölzl F, Buhl M, Autenrieth I, et al. Evaluation of phenotypic detection methods for metallo B lactamases (MBLs) in clinical isolates of Pseudomonas aeruginosa. Eur J Clin Microbiol Infect Dis, 2014; 33 (7): 1133-41.
8. Sánchez A, Gattarello S, Rello J. New treatment options for infections caused by multiresistant strains of Pseudomonas aeruginosa and other nonfermenting Gram negative bacilli. Semin Respir Crit Care Med, 2011; 32 (2): 151-8.

9. Szejbach A, Mikucka A, Bogiel T, Gospodarek E. Usefulness of phenotypic and genotypic methods for metallo beta lactamases detection in carbapenem resistant Acinetobacter baumannii strains. Med Sci Monit Basic Res, 2013; 19: 32-6.

10. Gupta V, Garg R, Garg S, Chander J, Attri AK. Coexistence of extended spectrum betalactamases, AmpC beta lactamases and metallobeta lactamases in Acinetobacter baumannii from burns patients: a report from a tertiary care centre of India. Ann Burns Fire Disasters, 2013; 26 (4): 189-92.

11. Bialvaei AZ, Samadi Kafil H. Colistin, mechanisms and prevalence of resistance. Curr Med Res Opin, 2015; 31 (4): 707-21.

12. Hsueh PR, Chen WH, Luh KT. Relationships between antimicrobial use and antimicrobial resistance in Gram negative bacteria causing nosocomial infections from 1991-2003 at a university hospital in Taiwan. Int J Antimicrob Agents, 2005; 26 (6): 463-72.

13. Lai CC, Wang CY, Chu CC, Tan CK, Lu CL, Lee YC, et al. Correlation between antibiotic consumption and resistance of Gram negative bacteria causing health care associated infections at a university hospital in Taiwan from 2000 to 2009. J Antimicrob Chemother, 2011; 66 (6): 1374-82. 
14. Yan JJ, Wu JJ, Tsai SH, Chuang CL. Comparison of the double disk, combined disk, and $\mathrm{E}$ test methods for detecting metallo beta lactamases in Gram negative bacilli. Diagn Microbiol Infect Dis, 2004; 49 (1): 5-11.

15. Kaleem F, Usman J, Hassan A, Khan A. Frequency and susceptibility pattern of metallo beta lactamase producers in a hospital in Pakistan. J Infect Dev Ctries, 2010; 4 (12): 810-3.

16. Aksoy MD, Cavușlu S, Tuğrul HM. Investigation of metallo beta lactamases and oxacilinases in carbapenem resistant Acinetobacter baumannii strains isolated from inpatients. Balkan Med J, 2015; 32 (1): 79-83.
17. Vasoo S, Barreto JN, Tosh PK. Emerging Issues in Gram negative bacterial resistance: An update for the practicing clinician. Mayo Clin Proc, 2015; 90 (3): $395-403$

18. Abdallah $M$, Olafisoye $O$, Cortes $C$, Urban $C$, Charles C, Landman D, et al. Reduction in the prevalence of carbapenem-resistant Acinetobacter baumannii and Pseudomonas aeruginosa in New York City. Am J Infect Control, 2015; pii: S0196-6553(15) 00114-5. 